\title{
Toward a Re-thinking of Mass Public Schooling: A Personal Exploration
}

\author{
LeRoy E. Whitehead
}

Queen's University

\begin{abstract}
Mass public schooling as we know it was one result of the industrial revolution. Its organizational form was heavily influenced by the 'code' of industrialism, the scientific management movement and industrial bureaucracy. While the promise of the philosophy underlying the use of the bureaucratic form in social institutions is tempting, the literature of bureaucracy indicates that bureaucratic organizations are most successful when certain preconditions are met, less successful when they are not. These preconditions are increasingly absent from our schools, school systems and the environment in which they operate. Hence, the bureaucratic form is increasingly counter-indicated, and its continued use may be a contributing factor in what appears to be a growing level of dissatisfaction with the system and dysfunction in the system. By recognizing a distinction between the terms 'education' and 'schooling' we may be able to move beyond mass public schooling to a situation in which the public is well-educated.
\end{abstract}

Key words: bureaucracy and schooling, education and schooling, school organization

RESUMEN

La escuela de masas, tal como la conocemos, fue un resultado de la revolución industrial. Su forma de organización estuvo profundamente influída por el "código" de la industrialización, el movimiento de gestión científica y la burocracia industrial. Mientras que la promesa de la filosofía que subyace al uso de la forma burocrática en las instituciones sociales resulta atractiva, la literatura acerca de la burocracia indica que las organizaciones burocráticas tienen más éxito cuando se dan ciertas precondiciones, y menos cuando no se dan. Estas precondiciones están cada vez más ausentes en nuestras escuelas, nuestros sistemas escolares y los entornos en los que operan. Por tanto, la forma burocrática está vez más contraindicada, y su uso continuado es, quizás, un factor que contribuye a lo que parece ser un creciente nivel de insatisfacción con el sistema y de disfunción en el sistema. Mediante el reconocimiento de una distinción entre los términos "educación" y "escolarización", podemos ser capaces de ir más allá de la escuela de masas, a una situación en la que el público sea bien-educado.

Descriptores: burocracia y escuela, educación y escuela, organización escolar.

RÉSUMÉ

La scolarisation de masse comme nous la connaissons fut un résultat de la révolution industrielle. Sa forme organisationnelle fut lourdement influencée par le 'code' de l'industrialisme, le mouvement scientifique et la bureaucratie industrielle, Quoique la promesse de la philosophie sous-jacente à l'usage de la forme bureaucratique dans les institutions sociales soit attrayante, la 
littérature de la bureaucratie indique que les organisations bureaucratiques sont le plus réussies quand certaines conditions préalables existent, et moins, quand elles sont absentes. Ces préconditions sont de plus en plus absentes de nos écoles, de nos systèmes scolaires et de l'environnement dans lequel ils opèrent. Donc la forme bureaucratique est de plus en plus contreindiquée, et la continuation de son usage peut être un facteur annexe dans ce qui apparait être un niveau grandissant d'insatisfaction du système et de dysfonction au sein du système. En reconnaissant une distinction entre les termes 'éducation' et scolarisation' peut-être pourronsnous devenir capables de dépasser l'instruction publique de masse et arriver à une situation où le public est bien-éduqué.

Mots-clés: bureaucratie et scolarisation, éducation et scolarisation, organisation scolaire.

Critical examination of its own underlying principles.
critich is not based upon - John Dewey, Education and Experience

As the saying goes, there is both good news and bad news. The good news is that our system of mass public education is helping more people learn how to read and write than ever before in history. More students are graduating from secondary school than ever before, and more are proceeding to post-secondary education than ever before. The bad news is that there are disquieting indicators of significant dissatisfaction with our school system on the part of parents, students and the general public, and indicators of dysfunction within the system. To use an aeronautical metaphor, we are beginning to see cracks in the fuselage of our school system. The organizational equivalent of metal fatigue is beginning to set in.

It would be overly simplistic to attribute such dissatisfaction and dysfunction to any single cause: clearly there are very likely multiple causes. However, I believe that at least some of the problems we are now encountering are attributable, at least in part, to a growing mismatch between the increasingly centralized, increasingly bureaucratic organizational structure of the system on the one hand, and the radically changing social and political environment in which the schools operate on the other. I fear that if we do not begin to re-think the way we currently organize for education, the mismatch, and the dissatisfaction and dysfunction arising from it, will continue to grow, leading eventually to disastrous results. At the very least we will lose the benefits for both individuals and society that a more open and innovative approach to education might provide.

In this brief, exploratory essay, I will first point to what I consider to be some of the leading kinds of indicators that constitute evidence of the dissatisfaction and dysfunction, hence evidence of the mismatch, of which I write. Second, I will sketch the basic outline of an argument grounded in organization theory that can link the current factory school model and the bureaucratic organizational structure of the school system to the indicators, though a complete elaboration of both the argument and the linkages would require a much longer discussion than is possible here. The reader will have to contribute some of the effort at this point. I will suggest that we draw a distinction between education and schooling, in the hope that recognizing a difference between the two concepts, and more clearly delineating the relationship between them, will help us 
move beyond mass public schooling to a situation in which the public, en masse, become well-educated. My intent in this essay is simply to show that there is enough of a case to warrant undertaking a full and detailed discussion of the issues. Using a legal simile, this essay should be considered akin to a preliminary hearing for the purpose of considering whether there is sufficient evidence to proceed to a full trial. Clearly, I believe that there is.

\section{Cracks in the Fuselage: Indicators of Dissatisfaction and Dysfunction}

Those aspects of things that are most important are hidden because of their simplicity and familiarity.

\section{- L. Wittgenstein, Philosophical Investigations}

My list of indicators and examples will all be with reference to Canada and the United States of America, because these are the jurisdictions with which I am most familiar. Canada and the United States are similar in that both are federal states in which the constituent states or provinces have retained governing authority over education. I suspect, however, that similar indicators will be found in other countries as well, including non-federal states. This listing of indicators and examples is intended to be illustrative only, not exhaustive, and is intended more to remind readers of things they already know than to inform them of things with which they are not familiar. The selection of examples may appear to be fairly random, and in a sense it is. I have been collecting examples from various news media for several years, as they have caught my attention and interest. The selection that appears below represents only a part of the full collection. I believe, however, that when we take a step back and consider the seemingly random and disparate phenomena in light of what we know about the conditions in which different forms of organization function best, a pattern begins to emerge.

I have grouped the indicators in five categories: families and individuals abandoning the public school system in favor of other educational alternatives, families remaining with the public school system but seeking additional support from other sources, individuals leaving school prematurely (dropouts), concerns regarding safety and health at school, and a growing polarization in society that is reflected in increasingly polarized attitudes toward the mass public school system.

\section{Families and Individuals Abandoning the Public System}

There are a proportionally small but continually growing number of families and individuals who are abandoning the public school system and migrating to private schools, home schooling and online academies. These families and individuals cite a variety of reasons, including the perception of low academic standards, poorly qualified teachers, lack of discipline (or too much discipline), lack of congruity between the moral, reli- 
gious, ideological and/or political values espoused by the family and those promulgated by the school, as well as unsafe conditions at the school, including both the possibility of physical violence and health hazards such as asbestos dust and mold in old school buildings and portable classrooms.

- Example: in the Province of Ontario, Canada, between 1996 and 2004, the number of children attending private schools increased by 40 per cent. ${ }^{1}$

- In Canada, an estimated 2,000 children were being home schooled in 1979. By 1996, this estimated had grown to 17,523 , though home schooling associations claimed a much higher total of between 30,000 and 40,000. An estimate published in 2000 put the figure at more than 80,000 . In the United States, data published by the National Center for Education Statistics (1999) estimated the number of homeschooled students at 850,000 , or 1.7 percent of the total student population. ${ }^{2}$

- Example: the Ontario provincial Education Quality and Accountability Office implemented a standardized grade 10 literacy test in the 2000-2001 school year. The failure rate was nearly one-third. Sixty-nine per cent of girls passed both the reading and writing components, compared to only 55 per cent of boys. ${ }^{3}$ The results jumped to 75 per cent for girls and 68 per cent for boys for the October 2002 testing, perhaps because teachers had gained some familiarity with the test. By the March 2007 testing, the success rate for girls had risen to 87 per cent, and for boys to 80 percent. This represented an overall increase of $12 \%$ in the success rate between October 2002 and March 2007, but the gender gap in favor of girls has remained constant at 7 per cent since $2002 .{ }^{4}$

- Example: Statistics Canada recently reported that girls are outperforming boys in key skills by age five. The boys, apparently, are not yet ready for school at this age and have different learning styles. Family income and household environment are also key factors in readiness for learning. ${ }^{5}$ Some teachers say they are beginning to change the way they teach five year old boys. ${ }^{6}$

- Example: the most recent report of the U.S National Assessment of Educational Progress for grade 12 reading and mathematics (the survey was done in 2005) found that only 35 per cent of the representative sample of 21,000 students from 900 schools across the country were "proficient" in reading, down from 40 per cent in 1992. In the context of the study, "proficient" means competence at or above the eighth grade level. Twenty-seven per cent were found to be functionally illiterate. In math, only 23 per cent performed at or above the proficient level. ${ }^{7}$

\section{Families Seeking Additional Support}

There are a growing number of families who remain with the public schools, but who patronize an also growing number of commercial, after-school tutoring services, including well-organized and advertised store-front franchise organizations.

- Example: In Kingston, Ontario, the small city of 116,000 where I live, there are currently three franchised tutoring schools in operation, plus two or three more local operations. 


\section{Early School Leavers (Dropouts)}

The numbers of students leaving secondary school before graduation include disproportionately high numbers of boys, rural students, aboriginal students and possibly other identifiable groups as well.

- Example: in Canada, the proportion of dropouts who are male increased from 58 per cent in 1990-91 to 64 per cent in 2004-2005, not because more boys are dropping out, but because fewer girls are. ${ }^{8}$

- Example: prior to the introduction of a new curriculum in 1998, the high school graduation rate in Ontario was 78 per cent. By 2004, after the introduction of the new curriculum and apparently as a result of it, the graduation rate had declined to 68 percent. ${ }^{9}$ In October 2003, the Liberal Party of Ontario's winning election platform and subsequent "throne speech" (the formal announcement of the government's legislative agenda for the parliamentary session) included a proposal to lower the number of dropouts by increasing the legal dropout age from 16 to 18 . Recent developments in connection with this policy have included, among other things, plans to expand work experience programs for secondary school credits and more remedial assistance, especially in reading and mathematics. ${ }^{10}$

- We know that a substantial proportion of early school leavers are of above average intelligence.

\section{Safety and Health at School}

Wide-spread concerns about safety at school include, but are not limited to, bullying, theft, assault, sexual assault (by both teachers, other students and intruders), violence relating to the buying and selling of drugs, gang activity, kidnapping by non-custodial parents, random attacks by lone shooters and the possibility of terrorist attacks on schools. These concerns have led to, among other initiatives, the imposition of "zero tolerance" policies in many jurisdictions, the introduction of "lockdown" drills, and requirements for criminal records checks for teachers, staff and frequent visitors.

- Example: In the United States, a major report has been presented to the House Homeland Security Committee regarding the readiness of schools in all 50 states to deal with cases of full-scale terrorist attack, natural disaster or biohazard emergency.

- Example: many schools have instituted anti-bullying programs, and some have enacted dress codes that forbid the wearing of gang 'colors'. (I recently read a report of one study that found a particular anti-bullying program actually led to an increase in bullying behavior. Unfortunately, I have lost the reference.)

- Example: some of the results of zero tolerance policies can only be described as bizarre. One six year old child was suspended for bringing a plastic knife to school to cut cookies at lunch time. Another six year old boy was suspended for alleged sexual harassment. ${ }^{11}$ These are not isolated examples.

- Example: In Toronto, Ontario, the number of student suspensions rose from 17,371 in 2000-2001, before the introduction of the provincial 'safe schools' policy, 
to 24,238 in 2001-2002, after the implementation of the policy, an increase of about 40 per cent. ${ }^{12}$

\section{Growing Polarization}

There is yet another indicator that I believe is very significant, but more difficult to illustrate. It is what I perceive to be a growing polarization of opinion and hardening of attitudes in society generally. This polarization is reflected in attitudes toward the public school system, especially with regard to the question of which moral, religious, ideological and political values should be espoused and promulgated by the schools. The indicator is not just the number of people who hold differing views, but the growing militancy with which they hold those views, on both ends of the political continuum. Perhaps this growing unwillingness to compromise, to find common ground, is best illustrated by a still small but growing number of private, usually not-for-profit organizations that are willing to help aggrieved families and individuals finance and mount legal challenges against their schools and school officials. At one time we thought that the common experience of the public school would bring us all together as a community, but this assumes a certain level of coherence in society to start with. When litigants walk into court, notions of community fly out the window and it becomes "us against them." In reporting such incidents, the news media usually use the language of victory, of winner and loser. The social fallout may be with us for decades.

On the basis of these indicators, it seems clear that while our schools are working for some people, perhaps even most, there is a substantial portion of the population for which mass public schooling, as we know it, is not working well, or not working at all. In a way, mass public schooling is rather like mass public transit: it picks up a lot of people somewhere in the neighborhood where they are and drops them off somewhere in the neighborhood where they want to go. It is a bit slow because of the many stops along the way, and only by chance or good planning in terms of choice of residence and employment locations does any individual get door-to-door service. Many people can't really benefit from it, because it doesn't run close enough to their neighborhood.

It is not that we do not recognize that there are problems. We do, and well-intentioned people are seriously trying to solve them, but we are trying to solve them with the wrong tools: with increasingly bureaucratic solutions at a time when the bureaucratic approach is counter-indicated.

\section{Industrial Schools in a Post-Industrial Age}

They can have any color they want, as long as it's black. - Henry Ford, American industrialist

Mass public schooling, as we know it, is a product (dare I say a relic?) of the industrial age and is becoming increasingly anachronistic in the post-industrial era. In his analysis of the cultural "code" underlying industrialism, Toffler (1980) identified six key values that influenced (and continue to influence) virtually every aspect of industrial soci- 
eties, including schools, as follows. I will explain what each term means, and suggest one or two ways in which it has influenced thinking about schools.

- Standardization of process and product, with whatever identical "widgets"13 being produced having interchangeable parts. All students should go through the same process, study identical or at least similar curricula at the same age and come out thinking and acting pretty much the same. We call it "socialization." The secondary school graduation diploma should indicate that graduates have achieved a standard repertoire of facts, skills and attitudes.

- Specialization, meaning division of labor, with each job being done by a specialist. Instead of the one-room school, we developed the multi-room, multi-grade school with teachers who specialized in a particular grade level or a particular subject. There are other specialists, too, such as department heads, principals and vice-principals, superintendents, subject consultants, guidance counselors, secretaries, custodians, and so on.

- Synchronization. Factory workers start and end their work day when the whistle blows. Be there, and be on time. The school day begins, ends, and students move from class to class when the bell rings. Be there, and be on time. Take your vacations when everyone else does.

- Concentration of people, facilities and resources. Mass production required machines and large numbers of workers to come together in the same physical location. The internal combustion engine made school buses and hence the concentration of students and teachers at large consolidated schools possible. Children now commute long distances to school, some up to an hour and one-half one way.

- Maximization means "bigger is better," often for its own sake. Schools are bigger than ever before. We rationalize this with narratives about economies of scale and how more students in a single, bigger school make possible a broader range of course offerings and learning resources than are possible in smaller schools.

- Centralization of power. The centralization of power in the industrial bureaucracy is symbolized by the pyramidal organization chart. The history of public schooling over the past century and more has been one of increasing centralization of power at the state or provincial level. We are now hearing frequent suggestions that effective control of the curriculum, if not the school system itself, should be moved to the federal level. Federal governments are eager to influence schools by providing federal funds.

Callahan (1962) has documented in excruciating detail the eagerness with which American school administrators adopted the principles of the "scientific management" movement in the early 1900's, including the key principle of "one best way," which is that we must find the single, most efficient method of accomplishing any task, and then implement this method without deviation, by compulsion if need be. Canadian school administrators got on the same bandwagon. But it wasn't just industrial values and methods that were adopted by the schools. Many school trustees and their communities were especially proud of their big, new school buildings that were designed even to look like factories. 
The real metaphor of mass public schooling is not the teacher as lighter of fires, or the teacher as planter and nurturer of beautiful flowers. It is the school as factory, the teacher as production worker.

\section{Bureaucratic Schools in the Still-Bureaucratic Age}

The bureaucracy is like a big, old whale that has been washed up on the beach. It needs to be put back in the water, so you get everybody out and you go down to the beach and push on the whale. You push and push for all you're worth, but your arms just sink into the blubber up to your armpits and the whale doesn't move.

- D.K., retired federal civil servant ${ }^{14}$

The great empires of the past all had bureaucracies of one kind or another. Max Weber of Germany is usually credited as the great exponent of the bureaucratic form of organization in present age, but his writings were not translated into English until the 1930's. Some have suggested that because of the intervention of World War II, people in the English-speaking countries didn't have time to think about Weber's writings much until the post-war period. This may help explain why, in Canada and the United States, bureaucratization of the school system really began to escalate during the postwar period. The concepts of bureaucracy mesh very well with the code of industrialism and the scientific management principle of "one best way."

It is important to note in passing that while large organizations are often bureaucratic, size alone does not make an organization a bureaucracy. Some very large organizations are not very bureaucratic, and some small organizations can be very bureaucratic. Though bureaucracies tend to become rigid, it is probably best not to think about "bureaucracy" as a rigid category into which organizations either fit or do not. Instead, it is probably more helpful to think in terms of a hypothetical scale for measuring the degree to which an organization is more or less bureaucratic in nature.

So far as public social agencies (including schools) are concerned, we must consider that there are three fundamental principles underlying and rationalizing the use of the bureaucratic form of organization, as follows.

- Clients must be able to expect to be treated fairly. In other words, people in the same situation, or presenting the same set of circumstances should be treated the same way. This implies that decisions will be made on the basis of law, policy and precedent, rather than arbitrarily or at the whim and pleasure of the officers, administrators or teachers of the system. Clients may or may not have some choice available.

- Clients must be able to expect that their case will be dealt with by officers, who have a high level of competence and expertise at their jobs. Competence is typically developed and/or demonstrated either through lengthy formal training, a lengthy internship or apprenticeship, the passing of rigorous examinations, or some combination of these. Whatever the means of demonstrating competence, the criteria should be related to the tasks of the position. It has been observed that the continued use of classical examinations for entry into the bureaucracy, long after they ceased to be relevant, contributed to the overthrow of imperial China. 
- Clients should be able to expect that their cases will be handled in a timely and efficient manner.

Few would object to these three principles: fairness, competence and timeliness. Indeed, a large proportion of complaints about bureaucratic agencies are based on the perceived failure of a given agency with regard to one or more of these three principles. "I wasn't treated fairly," or "Those people are incompetent," or "It has been months and I haven't heard back from them yet." The irony is that to the extent that the agency is, in fact, unfair, staffed by incompetent people, or inefficient in dealing with cases in a timely manner, the complaint is not really about too much bureaucracy, but about the agency failing to meet the bureaucratic standard.

Beyond these underlying principles, there are a number of additional elements in the definition of bureaucracy. A discussion of these elements may be found in most comprehensive textbooks written for introductory survey courses on organization theory. ${ }^{15}$ Among these there are two additional elements of the definition that are particularly relevant to this discussion: a clear and explicit statement of organizational purposes and goals, and the technical competence of each member of the organization. ${ }^{16}$ I will also discuss briefly the way in which the use of the age-grade cohort as an organizing principle for schools violates the expectation of fairness. And finally in this section I will attempt to summarize briefly what we know about the kinds of situations in which the bureaucratic form will work well, and the kinds of situations in which it works poorly. The latter point is central to this entire discussion.

\section{Clear and Explicit Purposes and Goals}

The definition of bureaucracy includes a requirement for a clear and explicit statement of organizational purposes and goals. The province of Ontario, the jurisdiction in which I reside, has no such statement for its public school system. At least, I have not been able to find one in either the Education Act, the basic governing document of the system, or on the Ministry of Education's web site, the places one would most likely expect to find it. I suspect most jurisdictions in Canada and the United States are in a similar situation. ${ }^{17}$ Not only is there no such statement, there is no tacit agreement either.

There are many such statements promulgated by individuals and organizations, but they are private views, not official statements of the system. Some want the schools to be the repository and conduit of traditional morals and values. Others want the schools to build a new social order. ${ }^{18}$ Some want schools to focus on preparing students for employment. Others want schools to prepare students to be active participants in a free society. Neo-conservative and neo-liberal governments want the focus to be on measurable outcomes: higher test scores, more graduates, fewer dropouts, while teachers want the focus to be on the process of schooling. Some want the schools to be the main agent of socialization, hence to encourage convergent thinking. Others want schools to encourage critical thinking and/or divergent thinking and innovation. And because the schools can deliver a captive audience, virtually everybody wants to use the schools to propagandize their particular vision. 
Without an officially accepted statement of goals and purposes the system is rudderless and vulnerable to educational fads and fashions, to political pressure groups, and to the needs of every newly elected government that wishes to leave its mark on the system for political points. This contributes to the shifting, dynamic type of situation in which the bureaucratic form of organization does not perform well, as will be discussed below.

\section{Teacher Competence}

Having been associate dean of an Ontario Faculty of Education, responsible for the day-to-day management of its Bachelor of Education program for many years, I am painfully aware that the time allotted to initial teacher preparation in Ontario (an eight month program after a previous Arts or Science bachelor degree) is woefully inadequate to prepare new teachers for the realities of today's classroom. I cannot speak authoritatively about other jurisdictions in this regard, but I strongly suspect that the high rates of turnover in the United States among new teachers in their first five years of teaching are at least in part the result of inadequate initial preparation. Teachers who are inadequately prepared cannot serve their students well. I have written about this point elsewhere, and will not belabor it here.

\section{The Age-Grade Cohort}

The practice of using age-grade cohorts (having children start school and proceed from grade to grade on the basis of age, rather than on the basis of readiness to learn and mastery of the curriculum) is fundamentally flawed. We have known this for decades, but have done nothing about it. We know, for example, that boys are ready to learn at a different age, on average, than girls, and that in general a different style of teaching works better for them. The concept of the "bell curve" or "normal distribution" also tells us that at any given age level some children, both male and female, will be ready and capable of learning the materials presented in the grade level associated with their age within the allotted time, while others will not, and still others will be capable of working at a level beyond that grade. In essence, we are asking and expecting some children to learn things of which they are not yet capable and compounding the shortfall from year to year. We are asking others to accept boredom throughout their school careers. This practice is the shame of mass public schooling, and is a flagrant violation of the bureaucratic principle of fairness.

\section{Variables Affecting the Performance of Bureaucracies}

The bureaucratic form can be very effective and efficient in certain kinds of situations, much less so in others. There are two key variables at play. One is the degree of change in the environment in which the organization operates: is the environment stable with relatively little change? Or shifting and dynamic with much change? The other is the degree of homogeneity in the materials or clients the organization processes: is the organization dealing with a population of clients that are homogenous? Or heterogeneous? The 
interplay between these two factors helps determine the kind of organizational form that is likely to be most appropriate and effective in a given situation, as explained briefly below and summarized in Figure 1. Note that variations in each of the two factors should be considered as being distributed along a continuum, rather than as falling into discrete categories. For the sake of analysis, however, they are often presented as if the two ends of each continuum were categorical, creating a matrix with four quadrants. Figure 1 is adapted from Mintzberg (1983, p.144) and Hodge and Anthony (1991, p.131).

Quadrant 1 (in Figure 1) represents the combination of a stable environment with a clientele that is homogenous. This situation calls for a centralized, bureaucratic structure of low complexity. The emphasis is on the standardization of work processes, and on rules.

Quadrant 2 represents the combination of a shifting, dynamic environment with a clientele that is homogenous. This situation calls for an organizational structure of medium complexity with some decentralization. There is direct supervision of workers, but the emphasis is on planning.

Quadrant 3 represents the combination of a stable environment with a heterogeneous clientele. This situation calls for a decentralized structure of greater complexity that is tending less toward the bureaucratic organizational structure and more toward the organic (i.e., non-bureaucratic). The emphasis is on standardization of skills in the workforce, and on rules.

Quadrant 4 represents the combination of a shifting, dynamic environment with a heterogeneous clientele. This situation requires a very decentralized, organic organizational structure. Mutual adjustment, rather than rules, is the main coordinating mechanism, and the emphasis is on planning.

Hodge and Anthony summarize with two general principles:

1 The more homogenous and stable the task environment, the less the need for organizational complexity and the greater the use of rule making.

2 The more heterogeneous and shifting the task environment, the greater the organizational complexity, planning and decentralization. (1991, p. 131)

In the early part of the twentieth century, perhaps even into the 1950's and 1960's, in most jurisdictions in Canada and the United States, the environment in which mass public schooling operated could probably have been described as relatively stable, and the student-body as relatively homogenous. Then came the baby boom, the baby bust, the echo boom, bilingualism and biculturalism, radical shifts in immigration policies and migration patterns, multiculturalism, globalization, satellite telecommunications, desktop computers more powerful than the early computers that filled rooms, the internet and the World Wide Web, mainstreaming and special education, post-modernism and moral relativism, the decline of industrialism in the west, the rise of knowledge workers, concerns about climate change, and on and on. Toffler, in Future Shock (1970), documented what he considered at that time to be evidence of overwhelming change occurring at an accelerating rate. Of course, from his vantage point in 1970, he was not yet aware of the continuing, tumultuous change of the last three and one-half decades since his book was published. 
Figure 1

An organizational type for each of four environments

\begin{tabular}{|c|c|c|}
\hline \multirow{2}{*}{$\begin{array}{l}\text { Degree of sameness } \\
\text { in the environment }\end{array}$} & \multicolumn{2}{|c|}{ Degree of change (uncertainty) in the environment } \\
\hline & Stable & Shifting, dynamic \\
\hline Homogenous, simple & $\begin{array}{l}\text { Quadrant } 1 \\
\text { Bureaucratic } \\
\text { Low complexity } \\
\text { Centralization } \\
\text { Emphasis on rules } \\
\text { Standardization of } \\
\text { work processes }\end{array}$ & $\begin{array}{l}\text { Quadrant } 2 \\
\text { Organic } \\
\text { Medium complexity } \\
\text { Decentralization } \\
\text { Emphasis on planning } \\
\text { Direct supervision of workers }\end{array}$ \\
\hline Heterogeneous, complex & $\begin{array}{l}\text { Quadrant } 3 \\
\text { Bureaucratic } \\
\text { Greater complexity } \\
\text { Home unit specialization } \\
\text { Emphasis on rules } \\
\text { Standardization of skills }\end{array}$ & $\begin{array}{l}\text { Quadrant } 4 \\
\text { Organic } \\
\text { Most complex } \\
\text { Much decentralization } \\
\text { Emphasis on planning } \\
\text { Mutual adjustment }\end{array}$ \\
\hline
\end{tabular}

Source: Figure 1 is adapted from Mintzberg (1983, p.144) and Hodge and Anthony (1991, p.131).

My point is that many, if not most, mass public school systems in Canada and the United States are still using a bureaucratic form of organization appropriate for a quadrant 1 situation (a stable environment and a fairly homogeneous student body), when in fact they are in a quadrant 4 situation (a shifting, dynamic environment and a heterogeneous student body).

If we are in a quadrant 4 situation, as I believe we are, a quadrant 1 style centralized, bureaucratic organization focused on standardization of process and curriculum and relying on policies and rules as the means of coordination is likely to fail, or at the least, not function as effectively as a more appropriate organizational form might. Such an organization simply cannot keep up or cope with the kind of complexity that a Quadrant 4 situation generates. We are seeing the results already in terms of the indicators of dissatisfaction and dysfunction discussed previously.

Mintzberg has enumerated the kinds of dysfunctions that occur in highly formalized organizational structures, and this would include centralized bureaucracies such as our public school systems. Alluding to Argyris, Bennis, Likert and McGregor, all wellknown names in the study of organizations, he comments: 
They pointed out man's inherent propensity to resist formalization, and impersonalization, and they showed the organizational "pathologies" that result from excesses in this direction. The dysfunctional consequences take various forms: the ossification of behavior, with the automatic rejection of all innovative ideas, the mistreatment of clients, increases in absenteeism, high turnover, strikes, and sometimes the subversion of the operation (1983, pp. 36-37).

If the reader will compare Mintzberg's list of dysfunctions with the catalogue of dissatisfactions and dysfunctions cited earlier in this essay, it will be easy for the reader to see many connections. Certainly the refusal to move from age-based cohorts to some other system when the evidence of their malfunction is clear represents ossification of behavior and rejection of innovative ideas. When a government's first reaction to the dropout problem is to announce plans to make dropping out illegal for two additional years, rather than focusing first on repairing the system, is that not an instance of blaming the victims, of mistreating the clients of the system? If dropping out before graduation is the ultimate form of absenteeism, then absenteeism is certainly evident in the school system. (Dropouts aside, a number of years ago a group of colleagues and I were contracted by the government to do a study of absenteeism in Ontario secondary schools. Whenever we told people about this project, the almost universal first question was, "students or teachers?") Teacher drop-out during the first five years of their careers has been a serious problem in the United States and to a lesser extent in Canada. Teacher strikes have not been common, but there have been a few, including two occasions in Ontario over the last ten years. One occasion was a province-wide, illegal walkout that lasted about two weeks at both the elementary and secondary levels. And on two occasions over the past 10 years, for example, many Ontario secondary school teachers sought, fairly successfully, to subvert the government's legislated intention to eliminate grade 13 by encouraging students to return to school for a thirteenth year anyway. (This effort still continues. This spring, at my son's secondary school graduation ceremony, as each graduate walked across the stage to receive the graduation diploma, the announcer told the audience of the graduate's plans for the next year: post-secondary education, work, travel, etc. The number of graduates planning to return to secondary school an additional year for a "victory lap" was remarkable. And more remarkable, what should have been regarded as a failure of the system and passed over quietly was lauded publicly by the teachers as a positive development.) All of the dysfunctions listed by Mintzberg are present in the mass public school system.

We need to start moving away from the current "one best way" system of mass schooling to a system of de-massified education compatible with quadrant 4, from a centralized bureaucracy to a more decentralized and organic system that offers many options for education, perhaps even including factory schools for those who learn best in that kind of setting. We need to accept, from general systems theory, the concept of "equifinality"- the concept that there are many ways to achieve the desired outcome. ${ }^{19}$ 


\section{Re-thinking the Relationship Between Education and Schooling}

I have never let my schooling interfere with my education.

- Mark Twain, American author and satirist

To help facilitate a change in thinking about the way we organize for education, we might do well to begin by changing our thinking about the relationship between education and schooling. At present, we tend to use the words education and schooling interchangeably, as if the two terms were synonymous. They should not be. Education is the goal, the desirable quality that we wish our citizens to attain. Mass public schooling is merely the means, the technology, that we have chosen to use to produce (or evoke, if you prefer) the state of being educated. We could, if we so chose, begin to use different means, different technologies, and different organizational structures instead to produce the state of being educated. Indeed, part of the evidence for the existence of dysfunction in the public school system is the growing number of people who are already opting for other means of achieving education, such as private schools, home schooling and online academies. Some are also promoting plans that would fund individual students by means of vouchers to be used at any school, public or private, rather than funding the system.

I want everyone to be well-educated, because an educated citizenry is the bedrock of a free society, which I value highly. It does not follow, however, that I necessarily want everyone to attend school. Nor does it follow that one must attend school to be educated. Indeed, for some people, the technology of schooling impedes the attainment of their education.

We must support publicly-funded experimentation with a wide variety of alternative, innovative methods for achieving education. We need innovations that will lead us away from quadrant 1 organizational forms toward quadrant 4 organizational forms, away from the factory school model of the industrial age toward a variety of approaches to education congruent with the post-industrial age. How can we judge which innovations will move us away from the industrial model of mass schooling toward more appropriate models?

In Creating a New Civilization: The Politics of the Third Wave, Alvin and Heidi Toffler propose five principles for a new civilization in the post-industrial world. These principles may be useful in considering a new approach to evaluating proposed innovations in a de-massifying education system appropriate for quadrant 4 . Each principle is represented by a question. Along with each question, I will provide a brief quote to indicate the flavor of the principle. Note that in the Tofflers' words the term "Second Wave" refers to the industrial civilization, "Third Wave" refers to the emerging postindustrial civilization.

- Does it resemble a factory? If a proposal merely seeks to improve factory-style operations or create a new factory... it is not Third Wave.

- Does it massify society? Second Wavers want to retain or restore the mass society. 
Third Wavers want to figure out how to make de-massification work for us.

- How many eggs in the basket? Putting eggs in many baskets, instead of all in one, is hardly a new idea, but it is one Second Wavers hate.

- Is it vertical or virtual? Second Wave organizations accumulate more and more functions over time and get fat. Third Wave organizations, instead of adding functions, subtract or subcontract them to stay slim. As a result, they outrace the dinosaurs when the Ice Age approaches.

- Does it empower the home? The Third Wave empowers the family and the home. It restores many lost functions that once made the home so central to society. An estimated thirty million Americans now do some part of their work at home, often using computers, faxes, and other Third Wave technologies. Many parents are now choosing to home-school their kids, but the real change will come when computerscum-television hit the household and are incorporated into the educational process (1994, pp. 82-88).

\section{Conclusion}

I never ruled Russia; ten thousand clerks ruled Russia.

- Tsar Nicholas II

Though this essay has provided only a brief outline of the argument, I believe it demonstrates the need for a full examination and discussions of the dysfunctions and limitations of bureaucracy for effective education in a dynamic and constantly changing, heterogeneous society such as the one in which we now live. It indicates the nature of the case that has yet to be fully made that other conceptions of education and schooling, as well as other forms or organization for the purpose of achieving an educated society, must be considered. Other views will be welcome. Let's begin the discussion. 


\section{Notes}

1 Statistics cited 3 May 2004 by Gerard Kennedy, Minister of Education for the Province of Ontario. "Government committed to excellence for students," downloaded from the Government of Ontario web site news page on 13 August 2007. http://ogov.newswire.ca. See also, for example, "Why Some Ontario Parents and Guardians Choose Private Schooling," John Mirski, Master of Education Thesis, Queen's University, Kingston, Ontario, 2005.

2 Statistics and studies cited in Basham (2001).

3 "Third of students fail test in literacy," Toronto Star, 7 March 2001, p. A1.

4 Education Quality and Accountability Office, "Onatrio Student Achievement: EQAO's Provincial Report on the Results of the 2006-2007 Ontario Secondary School Literacy Test," p. 13. Downloaded from the EQAO web page 17 August 2007. http://www.eqao.com .

5 "Girls outperforming boys in key skills by age 5, StatCan says," National Post, Toronto, Ontario, 28 November 2006, p. A12.

6 "Girls beat boys in school readiness," Toronto Star, Toronto, Ontario, 28 November 2006, p. A1.

7 "The Nation's Report Card: 12th Grade Reading and Mathematics 2005," Executive Summary. NCES number 2007468, release date 22 February 2007. Downloaded 17 August 2007. http://nces.ed.gov/nationsreportcard/ . See also commentary in Canadian edition of Time, 25 June 2007.

8 "Lessons in Learning: Canada's high-school dropout rates are falling," Canadian Council on Learning, posted 16 December 2005. Downloaded from the Council's web site on 13 August 2007. http://www.ccl-cca.ca

9 "Helping students succeed instead of dropping out," News release, Ontario Ministry of Education, 14 October 2005. Downloaded from the Ministry web site news page on 13 August 2007. http://www.edu.gov.on.ca .

10 "Ontario Goes Liberal," Canada Online, posted 3 October 2003. Downloaded from the Canada Online web page 13 August 2007. http://canadaonline.about.com/b/a/031568.htm.

11 See, for example, "Zero tolerance runs amok," The Washington Times web page. Published 18 June 2007. Downloaded 18 June 2007. www.washingtontimes.com . See also, for example, the egregious case of the six year old boy who was suspended for alleged sexual harassment: "Boy, 6, jumps from tub into sexual harassment trouble," The Canton Repository, posted 11 May 2000. Downloaded 16 August 2007. http://www.cantonrep.com .

12 "Safe Schools Act brings jump in suspensions," The Kingston Whig-Standard, Kingston, Ontario, 22 July 2002, p. 11.

13 "Widget" is a nonsense term used by professors of management as a generic word meaning products being produced by a factory.

14 Personal conversation.

15 For example, Hodge and Anthony (1991) p. 326 and following. See also Mintzberg (1983) pp. 35-36.

16 Hodge and Anthony, p. 327.

17 The previous neo-conservative government of Ontario produced a small leaflet outlining its goals for the system, but this seems to have vanished when the new, neo-liberal government took office in 2003.

18 The reference is to Counts (1932).

19 Our grandparents would have simply said, "There are many ways to skin a cat." Please excuse the images of violence toward animals that this old adage invokes. 


\section{References}

Basham, P. (2001). Home schooling: From the extreme to the mainstream. Public policy sources number 51. Vancouver, BC: The Fraser Institute.

Callahan, R. E. (1962). Education and the cult of efficiency. Chicago: University of Chicago Press.

Counts, G. S. (1932). Dare the school build a new social order? Reprint edition (1969). New York: Arno Press and The New York Times.

Dewey, J. (1938). Experience and Education (p. 22). New York: Collier Books, The Macmillan Company. Twelfth printing, 1970.

Hodge, B.J. and Anthony, W.P. (1991). Organization theory: A strategic approach, Forth edition. Boston: Allyn and Bacon.

Mintzberg, H. (1983). Structure in fives: Designing effective organizations. Englewood Cliffs, NJ.: Prentice-Hall, Inc.

Toffler, A. (1970). Future shock. New York: Random House, Inc. Bantam Books edition (1971).

Toffler, A. (1980). The third wave. New York: William Morrow \& Co., Ltd. Bantam Books edition, seventh printing (1982).

Toffler, A. and Toffler H. (1994). Creating a new civilization: The politics of the third wave. Atlanta: Turner Publishing, Inc.

Whitehead, L.E. (2007) How long should it take to become a teacher? In Education Letter (pp. 4-5). Spring-Summer 2007, pp. 4-5. Kingston, ON: Queen's University Faculty of Education. 
220 Encounters/Encuentros/Rencontres 